\title{
Untribing the (Post)-Colonial Spanish Archives: Material Records, Boundary-making and Linguistic Diversity within Northern Morocco's Berberophones
}

\author{
Araceli González Vázquez \\ Consejo Superior de Investigaciones Científicas. Institución Milá y Fontanals (IMF) \\ e-mail: araceli.gonzalez@imf.csic.es \\ ORCID iD: https://orcid.org/0000-0003-4241-9347
}

Submitted: 26 February 2020. Accepted: 2 July 2020

\begin{abstract}
This paper analyses the linguistic diversity among the Berberophones in northern Morocco in the period of the Spanish Protectorate in Morocco (1912-1956). To do this, I focus on the documentary materials kept in digital archives, which allow us to go deeper into the knowledge of how Spaniards may have shown interest in Berberophony. In particular, I centre my analysis on the recognition of linguistic diversity and on the process of recognising linguistic borders enacted in the colonial era. I add some reflections on the persistence of colonial discourses in the postcolonial era.
\end{abstract}

KEYWORDS: Colonialism; Postcolonialism; Archives; Berbers; Amazigh; Morocco.

Citation / Cómo citar este artículo: González Vázquez, Araceli (2020) "Untribing the (Post)-Colonial Spanish Archives: Material Records, Boundary-making and Linguistic Diversity within Northern Morocco's Berberophones" Culture \& History Digital Journal, 9 (2): e016. https://doi.org/10.3989/chdj.2020.016

RESUMEN: Detribalizando los archivos (post)-coloniales españoles: registros materiales, construcción de fronteras y diversidad lingüistica entre los berberófonos del norte de Marruecos.- Este artículo analiza la diversidad lingüística entre los berberófonos del norte de Marruecos en el período del protectorado español en Marruecos (19121956). Para hacerlo, me centro en materiales documentales custodiados en archivos digitales, que nos permiten profundizar en el conocimiento sobre la forma en que los españoles se mostraron interesados en la berberofonía. En particular, centro mi análisis en el reconocimiento de la diversidad lingüística y en el proceso de reconocimiento de fronteras lingüísticas llevado a cabo en época colonial. Añado a ello algunas reflexiones sobre la persistencia de los discursos coloniales en la era postcolonial.

PALABRAS CLAVE: Colonialismo; Postcolonialismo; Archivos; Bereberes; Amazigh; Marruecos.

Copyright: (C) 2020 CSIC. This is an open-access article distributed under the terms of the Creative Commons Attribution 4.0 International (CC BY 4.0) License. 


\section{INTRODUCTION}

The long and undoubtedly complex history of the Spanish expansion overseas from the 15th to the 20th centuries, in both America and Africa, but also in Asia, produced a very diverse collection of textual and visual materials, which has been preserved. This constitutes the Spanish imperial and colonial archive.

A substantial part of these textual and visual materials survives today in archives and libraries, not only in Spain, but also in many other countries around the world. In the case of the Spanish Protectorate in Morocco (1912-1956) these materials - which reflect, among other things, Spanish colonial action in northern Morocco in the first half of the twentieth century - are preserved mainly in the Archivo General de la Administración (AGA), located in Alcalá de Henares, a city in the Autonomous Community of Madrid, not far from the capital. This is one of six Spanish national archives, and is the third biggest archive in the world, after the US and French national archives.

In preserving the records of the Spanish Protectorate, mainly in its Fondo África (Africa Collection), the AGA becomes a "colonial archive", containing texts of different sorts in which the voices of the colonial agents and the Spanish nationals abound. The Biblioteca Nacional of Spain (BNE) in Madrid also hosts part of the colonial archive dealing with Morocco. The BNE's Sección África was created in 1966 mainly from the materials donated by a prominent member of the Spanish colonial army, Tomás García Figueras (1892-1981). Hence in this section, we find the Colección García Figueras, which is basically the personal archive of this highly relevant Spanish colonial agent and writer. In this article I will mention more than these two institutions - the AGA and the BNE - because the examples of "colonial archives" are multiple. Interestingly, the BNE's digital library, the Biblioteca Digital Hispánica, provides access free of charge to hundreds of digitised documents linked to the Spanish colonial action in Morocco, mainly books and maps. Another of the BNE's digitisation projects provides access to Spanish press materials. This is the Hemeroteca Digital. Together with the Biblioteca Virtual de Prensa Histórica created by the Spanish government, this repository provides access to the Spanish press of the colonial period. Between the years 1912 and 1927, years of open war in Morocco, many of the materials generated by Spanish colonial actions were materials of a military nature, hence the interest of another digital library that preserves these materials, the Biblioteca Virtual del Ministerio de Defensa.

All the aforementioned "colonial archives", the AGA, the BNE, the Biblioteca Virtual de Prensa Histórica and the Biblioteca Virtual del Ministerio de Defensa, among many others, keep records related to the Spanish colonial actions in two areas of northern Morocco: the so-called Berberophone areas of Ghomara and Senhaja de Sraïr, in the western and central Rif. As a particular feature in both territories, the Spanish colonial archive stresses the existence of villages and fractions of tribes inhabited by vernacular speakers of Berber (Amazigh, referred to mainly as chelja). These are speakers of what have been traditionally described as two different Berber "varieties", which are most frequently referred to by the names Ghomara and Senhaja de Sraïr (Gomara, Senhaya de Serair) Srair). Many different colonial texts that I have been able to retrieve from these archives help us fill in notorious gaps in the largely unwritten history of the Spanish colonial recognition of linguistic diversity within the Protectorate's territory, with a special focus on the case of Berber and the Berber varieties of Ghomara and Senhaja de Sraïr.

In the material records kept in colonial archives, both Ghomara and Senhaja de Sraïr are almost invariably understood as being two confederacies of tribes (confederaciones de tribus). In the Spanish colonial literature, the word tribu (tribe) is thought to translate the Arabic singular qabila, which is clear evidence of the impact of French colonial literature referring to, first, Algeria and then Morocco. In the use of the term confederacy (confederación), we can also see the influence of French colonial literature. In their use of these terms, Spanish texts rely less on local knowledge than they do on French colonial knowledge. Rather than stemming mainly from studies of the local forms of political government and the local alliances between groups, the Spanish relied with some frequency on previous affirmations contained in French literature. Rather, this does not mean that both colonial powers always agreed on the terms used to classify human groups: the example of the Beni Zeroual, a pre-Riffian tribe located to the north of the city of Fes, between the Ouergha River and the western Riffian chain, reflects the existence of debates between the French and Spanish governments and colonial agents. The fact that Beni Zeroual is a tribe and not a confederacy is the object of some disagreements, with the French frequently affirming that Beni Zeroual is a tribe, while the Spaniards maintain that it is a confederacy. The linguistic identity of all these groups, particularly their berberophony, has a role not yet addressed in the "tribing" and "untribing" of Morocco. In this article, I would like to explore the sense in which language and the linguistic identity of the "tribes" and the "confederacies" were and still remain meaningful tools linked to two sets of processes: on the one hand, the colonial perception of local boundaries and boundary-making itself (tribing), and, on the other, the postcolonial perceptions of colonial boundaries (both tribing and untribing, understood here as ways of conceiving both human groups and alliances). But let me say a few words on the term "untribing", which is crucial. I use this term as suggested by a book recently published by Carole Hamilton and Nessa Liebhammer (Hamilton and Liebhammer, 2016). Its title is Tribing and Untribing the Archive and it emerged from a workshop that brought together established and emerging archaeologists, historians, anthropologists and curators focusing on the material culture archive pertinent to the ThukelaMzimkhulu region in South Africa. Taking up Hamilton and Liebhammer's use of untribing, I suggest that Ghomara and Senhaja de Sraïr, but also Beni Zeroual (as well as Guelaya, in the Rif), can be taken as highly eloquent 
examples of the aforementioned colonial and postcolonial practices. Are local languages/varieties relevant in the case of the colonial perception of local boundaries and colonial boundary-making? Are local languages/varieties relevant in the postcolonial persistence of Spanish colonial perceptions of tribal/confederal boundaries and local alliance systems?

\section{LINGUISTIC DIVERSITY AND COLONIAL BOUNDARY-MAKING}

As many different researchers have underscored, Morocco's current linguistic profile is a result of the complex interaction between historical processes such as the medieval (and late) q, the colonial policies towards Arabic and Berber, and the nation-building processes promoting Arabic as a national language. All these processes reflect intense power relations. In present-day literature on Morocco, there is a widespread consensus that the confederacy is a Berber institution which reflects a long-standing past or present alliance between tribes. In the case of Ghomara and Senhaja de Sraïr, these were not tribes with a common form of government, but tribes taking part in a certain sort of alliance. In some texts produced by the French and the Spanish, the tribes that were supposed to be part of a confederacy were said to have a "leff"-style alliance (a local form of alliance sometimes written as left or liff) (Hart, 1966, p. 193).

In this paper, I do not intend to delve into the debate on the social organisation of North African Muslim tribal groups, which is already well nurtured by contributions from Robert Montagne (1931, 1973), Jacques Berque (1954), Ernest Gellner (1969), Paul Pascon (1971), David M. Hart (1970a and 1970b; 1984; 1989; 1993; 1996), Dale F. Eickelman (1976), Clifford Geertz, Hildred Geertz and Lawrence Rosen (1979), Marie Elaine CombsSchilling (1985), Henry Munson (1981; 1989; 1991; 1993; 1996), and William Kraus (1998). Rather, I want to stress that if we aim to better understand how the colonial archive is presently used (mainly through its digitised items) as a means to preserve and reproduce Spanish colonial perceptions of the linguistic (Arabophony/Berberophony divide) and socio-political boundaries in the Rif (particularly as to what is referred to as a tribe and a confederacy), we have to take into account what present-day linguistic research says about linguistic diversity within Berber.

The linguistic identities of Ghomara and Senhaja de Sraï are currently under research (El Hannouche, 2008; Mourigh, 2016), as are their links to other Berber varieties, mainly Riffian. In her Atlas linguistique des varieties berbères $d u$ Rif, published in 2007, the linguist Mena B. Lafkioui uses data from 16 points of research on the tribes belonging to Senhaja de Sraïr. In one of her latest articles, she states that Senhaja Berber is no other thing than western Tarifiyt (western Riffian). As such, it would not be possible to assert that socio-political boundaries are neat linguistic boundaries. In the case of Ghomara, we have no linguistic study that helps determine if the Berber Gho- mara variety the Berber linguistic substrate that was once extended within the Jbala: if this were the case, it would not be exclusively present-day-Ghomaran in the sociopolitical sense. The old colonial maps showing the linguistic boundaries between tribes and confederacies have a vivid post-colonial life thanks to digitisation processes, while others, like Lafkioui's, that show a different vision of linguistic continuities and discontinuities, remain largely unreproduced by local agents. In this article, I will reflect on how the present-day local use of Spanish colonial material records showing colonial conceptions of linguistic boundaries helps re-enact the colonial conceptions of linguistic diversity. As these conceptions have remained largely obscured in the bibliography on the Spanish Protectorate, I will devote a section of my article to them, trying to explain the main Spanish actions and attitudes towards linguistic diversity in order to help better understand how colonial linguistic boundary-making operated. This will provide the necessary context for understanding the two material records related to linguistic boundary-making I am focusing on. These are two maps that are rather popular nowadays when it comes to representing the linguistic identity of Senhaja de Sraïr and Ghomara. The first appeared in the Diccionario españolsenhayi (Dialecto bereber de Senhaya de Serair) published by Father Esteban Ibáñez, a Castilian Franciscan friar who had lived in Morocco for a long time (Ibáñez, 1959). In this dictionary, Esteban Ibáñez includes a "Mapa lingüístico de Senhaya de Srair". In it, the tribes of Buchibet and Targuist appear (in white) as Arabophone tribes; Quetama appears (in blue) as a bilingual tribe; Tagsut and Beni Mesdui appear (in yellow) as Berberophone in transition tribes; and Beni Seddat, Beni Jennus, Beni Buensar, Beni Ahmed, Beni Bechir and Sarcat appear (in red) as Berberophone tribes. This map is quite popular, and has been repeatedly reproduced locally, particularly since the 2000s. The other item is the map entitled "Mapa Sociológico de la zona de influencia española en el norte de Marruecos" created by Antonio Martínez Pajares, probably in the year $1916^{1}$. The first interesting issue is that Martínez Pajares presents himself as a Doctor en Derecho ( $\mathrm{PhD}$ in Law), and not as a cartographer. We find the "Mapa Sociológico" (as I will refer to it from here onwards) in several different archives. Two different archives have digitised this map, where it is available to be downloaded for free: the Biblioteca Virtual del Ministerio de Defensa and the Institut Cartogràphic i Geològic de Catalunya (ICGC). An eloquent dedication to Juan de la Cierva, Spanish Minister of War at that time, is handwritten on the map kept at the Centro Geográfico del Ejército (the Army's Geographic Centre). This map depicts both Ghomara and Senhaja de Sraïr. While Senhaja appears as a confederation of tribes, Ghomara appears as an empty space, with no political or administrative subdivision. This is, Ghomara appears completely untribed. The map puts into circulation very biased ideas of linguistic diversity in Northern Morocco.

The case of Beni Zeroual, which works in this article in counterpoint to those of Ghomara and Senhaja de Sraïr, 
is particularly interesting. In the French and Spanish colonial literature, this group appears variously as an Arabophone tribe/confederacy, an Arabised Berberophone tribe/ confederacy, or as a Berber tribe whose linguistic identity is disputed. The fact that it is taken for a confederacy is understood by Spanish colonial agents as proof of its former and now lost Berberophony. Of the tribes belonging to the Ghomara and Senhaja de Sraïr - "confederacies" or tribes linked through local alliance systems at the times of the establishment of the Protectorate regime - some were Arabic-speaking tribes, some were Berber-speaking tribes, and some others, saliently in the case of Ghomara, being mainly Arabophone tribes, had a few fractions or villages where their inhabitants spoke Berber. The confederacy of Ghomara was said to consist of nine tribes. In two of them, as shown by an early study by Georges S. Colin, there were Berber-speaking hamlets. The confederacy of Senhaja de Sraïr was said to consist of seven or ten tribes, some of which were inhabited by Berberophones, while others were inhabited by Arabophones. In Senhaja de Sraïr, Berberophony was far more extended than in Ghomara, as it is today, with some tribes being entirely or almost entirely Berber-speaking. Because it refers to the boundaries of the confederacy, in its institutional sense, the colonial agents and scholars that wrote on the Senhaja de Srair discussed the belonging of some tribes to it. In the case of Ghomara, there was no room for disagreement. Political boundaries were not linguistic boundaries, and yet, many discourses underscore Berberophony as the salient feature when it comes to the existence of a supra-tribal sort of alliance.

\section{A PICTURE OF LINGUISTIC VARIATION AS COLONIAL DEBRIS?}

In a very interesting work, Ann Laura Stoler speaks of "imperial debris" in reference to the persistent traces of the colonial period "which continue to underpin many of the structures of thought of the putative postcolonial present" (Stoler, 2008, p. 191; Barclay, 2013, p. 9). Lately, we see the legacies of colonialism are being revisited, reengaged with and put up for present-day engagement by a diverse set of actors, but mainly by researchers and political activists. The aforementioned Spanish colonial maps are eloquent in this sense, particularly because they are widely reproduced by local agents when they want to affirm a linguistic and cultural identity.

As is well-known, the colonial archive is a space and a place fraught with many different, complex and challenging epistemological and methodological problems. One of them refers to what we, researchers, do with the contents of the archive. Another to what the local populations do with these contents. In a 2002 article, Ann Laura Stoler urged scholars to move from an "archive-as-asource" approach to an "archive-as-subject" approach. In her opinion, scholars "should view archives not as sites of knowledge retrieval, but of knowledge production, as monuments of states as well as sites of state ethnography" (Stoler, 2002, p. 87). Jean and John Comaroff have sug- gested that scholars should "create new colonial archives of [their] own" (1992, p. 34), urging us to pay attention to new kind of sources - mainly oral ones - but also bearing in mind that we need to turn from "an extractive to a more ethnographic project" (Stoler, 2002, p. 108). This is exactly where I would like to place this article regarding Berber linguistic varieties and colonial legacies in northern Morocco. In her very widely read 1985-88 chapter "Can the Subaltern Speak?" Gayatri Chakravorty Spivak questioned whether we can ever recover the voices of the oppressed (Spivak, 1985 and 1988). This is a particularly interesting question when we are dealing with colonial materials and linguistic varieties of Berber, and we wish to examine what we know about the management of linguistic diversity in times of colonial rule. In Spivak's sense, if knowledge is power, and imperial and colonial knowledge was founded upon binaries, as, for example, the Arab/Berber divide, challenging the binaries by revealing their limits serves as an alternative representational strategy. One of the most pervasive binaries in Morocco's colonisation was precisely this Arab/Berber divide (Aixelà-Cabré, 2017), and language and linguistic boundary-making are two of the main elements giving support to this dichotomy.

Edmund Burke has used the term "Moroccan colonial archive", alluding to "the writings in French, official and unofficial, about Morocco and Moroccans in the period 1880-1930" (Burke, 2007, p. 2). Although he states that he uses the term "at its broadest extent", it is rather evident that he is thinking solely about the French Protectorate, but some of his ideas could well fit into the case of the Spanish Protectorate. In his opinion, although marked by the "deforming lens of orientalism, the creation of the French colonial archive on Morocco was "a formidable intellectual achievement". He has also stressed that the way it imagined a "traditional Morocco" provided the chief justification for the French Protectorate (1912-56) as well as the template for the colonial state. And what is more striking, in important ways it "continues to inform the image of contemporary Morocco" (Burke, 2007, p. 3). Burke has stressed that the study of Berber populations was a "major theme in French social research". As has been shown, it is particularly difficult to retrieve "voices" and "languages" (in this case linguistic varieties of Berber) from the colonial archive, even if the materials preserved and digitised really provide the researcher with substantial evidence on language use. In many ways, the local point of view is inaccessible in the colonial archive, but why and how do we expect to find it? How do we reconstruct it (if we dare to)? For what purposes? Moreover, we must take into account that the archive's public is in the metropole, rather than in the colony, and, if focused on the colony, the archive aims mainly at reaching the colonizing community, not the colonised. Does digitisation change this?

Textual and visual materials are one of the main legacies of colonization processes worldwide. The knowledge embodied in these materials has been labelled "imperial" or "colonial". Knowledge production, accumulation and 
preservation were part of the colonial regime, not only as a mere exercise in record-keeping (as part of the administration and governance process), but as a means to create understandings of selfhood and otherness that legitimised and consolidated the colonial project and the colonial endeavour. In my research on the (re)cognition of linguistic diversity in the western, central and eastern Rif, I have been constantly confronted with certain types of colonial memories and colonial archives which raise very specific questions about the production of knowledge in colonial Morocco. It is not surprising that colonial agents, of whatever kind, produced texts about languages. It is intuitively rather obvious that languages were relevant objects of knowledge for the colonisers. And yet, surprisingly, Spanish colonisers did not produce many materials related to Berber varieties. The Spanish Protectorate was inhabited by Berber-speaking native populations, but the Spanish authorities rarely encouraged the study of the Berber varieties.

\section{LINGUISTIC VARIATION AND DIVERSITY WITHIN BERBER: HOW WAS IT RECOGNISED AND REINFORCED THROUGH SPANISH COLONIAL ACTION?}

In this article, I do not intend to explore the many contradictions between postcolonialism and institutional practices in the creation of a colonial history archive, in this case within a national archive. My main aim is to reflect on the ventures of digitised materials which convey ideas about linguistic diversity. As I have stated in a previously published work (González Vázquez, 2018), there is a strong link between the colonial Spanish and French projects and actions, and the recognition of linguistic variation and linguistic diversity within Arabic and Berber. Spanish colonial agents acting in the north of Morocco had to face linguistic variation within both Arabic and Berber. In the specific case of Berber, the Spanish dominated a territory with (from west to east) speakers of Ghomara (on the coasts of the Mediterranean and its hinterland), speakers of Senhaja de Sraïr (in the central Rif), and speakers of Riffian - also called Tarifiyt (in the eastern Rif). Linguistic pluralism within Berber was very differently addressed by the colonial agents who had been in the field. Many agents had a clear understanding of the existence of linguistic variation, while others did not. This was a result of field experiences, including a direct transfer of local knowledge from local interlocutors.

Spanish colonial attitudes towards Arabic, together with colonial actions, have been the subject of many different studies published in the last few years. By contrast, Spanish discourses and practices towards Berber and Berber linguistic varieties have been much more neglected in the academic bibliography (Tilmatine, 2011). Present-day linguists tend to make use of the colonial productions, but very rarely produce a critique of these materials. Empirical data are used, but the motivations behind these works are not sufficiently analysed. Spanish colonisation gave rise to a language hierarchy in which Spanish was considered the most prestigious language; behind it, Arabic was widely recognised as a language of culture. The real interest in Berber was rather limited. In fact, the Spanish colonial authorities facilitated the work of several scholars in the territory of the Protectorate, but very rarely carried out any study themselves. This is particularly so in the case of Carleton Coon, a North American anthropologist who gave some hints of the languages spoken in the territory of the Protectorate in his Tribes of the Rif, published in 1931, but most saliently in the case of Amédée Renisio, an Algerian-born French soldier who published his Études sur les dialects berbères des Beni Iznassen, du Rif et des Senhaja de Sraïr in 1932. Esteban Ibáñez, who authored the aforementioned dictionary of Senhaja de Sraïr, is the main Spanish author.

In the years of the establishment of the Protectorate and the Rif War (1912-1927), language was linked to the colonial penetration. Knowledge of the local varieties was weak, and normally linked to the military actions against the local populations. The link between linguistic knowledge and colonisation was particularly strong in the years after the peace of 1927, when many Spaniards stated the convenience of deepening knowledge of Berber varieties. This need, as I will show through various testimonies, may be placed within colonial interests. And yet, some significant "early voices" supported Berber studies. One of these "early voices" is Francisco Codera, a prominent Arabist who in 1899 affirmed the following:

Because our relations with the Moors of the neighbouring
Moroccan empire must these days, above all in the case
of war, be with the Moors of the Riff (sic), and many of
its cabilas speak Berber in some of their dialects, it would
be useful for our officials and interpreters to pursue the
study of this language along with Arabic; as this may
serve to aid relations with all of them, at least in the most
necessary. In many cases there may be great interest in
understanding them when they speak among themselves
in Berber, all the more so when, in general, they may
think they are not understood (Codera, 1899, p. 41).

In his Politica de España en África, published in 1907, the geographer Gonzalo de Reparaz Ruiz (19011984) expresses his ideas on how the colonisation of Morocco should be carried out. He also speaks about the learning/teaching of the local language:

There are no chairs of Berber (berberisco, in the original), nor have I heard of any being proposed. I nevertheless believe them to be even more necessary than Arabic ones, as Berber is the popular language and in many tribes is all that is spoken (Reparaz, 1907, p. 448).

He also refers to the opinion of the Real Sociedad Geográfica de Madrid:

For direct action on the Riffians (says the Real Sociedad Geográfica de Madrid in its abovementioned statement) their own Berber language should be cultivated, the use of which by the Spanish would be a source of pride to them and serve to unite them with us (Reparaz, 1907, p. 448). 
The relevance of studying the language was also stated very actively. For example, the Basque Franciscan Friar Pedro Hilarión Sarrionandia, who carried out important linguistic studies while living and working in Morocco, wrote a letter to the Spanish Minister of Public Education entitled "Noticia sobre la lengua que se habla en el Rif, lengua aborigen de todo el norte de África" dated 23rd of November 1909, stressing the relevance of Riffian (Sarrionandia, 1909 and Sarrionandia, 1910).

In 1919, Ángel Muñoz Bosque, the author of an educational book on a Berber variety (Riffian), published a press article entitled "La enseñanza del idioma bereber en España" (Muñoz Bosque, 1919) ${ }^{3}$. This is one of the most persistent calls for the learning and teaching of Berber in Spain and to Spaniards:

the most valuable element for entering the heart of an indigenous person in a country that must be subdued is knowledge of their language, once weapons have opened up the path (...) Berber studies should be encouraged, decisively and with great urgency (Muñoz Bosque, 1919).

In 1927, the geographer Gonzalo de Reparaz also linked the learning of Berber to colonial penetration/socalled pacification:

[Spain] can no longer seek a top-down domination of Morocco, although a bottom-up penetration remains within its power. It should seek to create a group of employees who know Chelja and speak it, revive the study centres in Córdoba and Granada, attracting Moroccan students to them (Reparaz, 1927, p. 8).

Gonzalo de Reparaz insists on the convenience of teaching Riffian, stressing a binary perception of linguistic diversity within the territory under Protectorate, with a Riffian section speaking Chelja (Berber) and a western section where Arabic is spoken. In that same year of 1927 - the year when the formal peace was declared -soldier Cándido Lobera offered some suggestions for the formation of colonial agents (interventores) and underscored the learning of Berber varieties:

The practice develops skills and puts them to the test, and contact with the indigenous people allows Arabic or Riffian to be improved, thereby providing the candidate with excellent conditions for the new disciplines and the title of colonial agent (interventor in the original) for the corresponding category. When it opens, the school can be filled with those who speak the Arabic language and the Berber dialect (Lobera, 1927, p. 1).

One of the few articles to deal explicitly with "Berbers" published in the time of the Protectorate appeared in the journal África, Revista de tropas coloniales. Cándido Lobera, then an soldier, politician, colonial agent, and founder of the journal El Telegrama del Rif ("La política bereber del Protectorado") (Lobera, 1926, p. 126), again stressed the need for experts in Berber, and he did so by translating the words of Resident General Hubert Lyautey:
We do not have to teach Arabic to populations that have always lived without knowing it, who have been fighting for three centuries against Arab assimilation (...) From the linguistic standpoint, we should assist their shift directly from Berber to French; for that purpose Berberists are necessary: our officials in the information service must study the Berber dialects (Lobera, 1926, p. 126).

And he concludes:

The area of the Spanish Protectorate is one of pure Berber stock, if the four largely Arabised belt cities of the Atlantic coast and the Moulouya basin are excluded. This is the strong reason we continue to follow the paths indicated by those with special studies and who possess the experience of a century of domination in Algeria (...), keeping the Riffians in their own environment and progressively preparing the development of their mentality towards Spanish ideas and conceptions (Lobera, 1926, p. 126).

In 1944, the ideas had not changed much. Vial de Morla (pseudonym of the soldier Tomás García Figueras) wrote in the newspaper La Vanguardia about the relevance of Berber, which shows the influence of Menéndez Pidal's ideas, focusing on two of them:

- the connection of the Berbers with the Iberians, which he understands that might have taken place as a result of the expansion of the Berbers;

- the connection of Riffian with Basque and the "primitive language of the Canarians" (Vial de Morla, 1944, p. 1).

Indeed, one of these ideas, the identification of Riffian with Basque, is a relatively common topos: the colonial subject/external "other" is identified with the internal "other".

In order to characterise the Spanish colonial actions towards Berber, and the place given to variation in the colonial discourses and actions, I hereafter provide an account of the most important actions carried out by the Spaniards. Long before the establishment of the Spanish Protectorate in 1912, in the old days of the so-called Guerra de África (Hispano-Moroccan War), including the Spanish occupation of the city of Tetouan in 1859-62, a Riffian variety had been the object of Spanish interest. Among the first works with some linguistic content to be published in Spanish we find the book Un prisionero en el Riff. Memorias del ayudante Álvarez written by the dramatic author Manuel Juan Diana (1814-1881). It deals with the captivity of an Asturias-born soldier called Francisco Álvarez Jardón (born 1826). The book contains a lexicum of dozens of words in both Moroccan Arabic and the Moroccan Berber Riffian variety. It is entitled: Vocabulario de algunas palabras del dialecto riffeño, que viene a derivarse del árabe, y en pequeñisima parte del castellano ${ }^{4}$. It is followed by some "frases $y$ adverbios". A close look at the vocabulary shows that most of the words included are Moroccan Arabic words, while only a few of them form part of a Riffian variety. 
From the 19th century onwards, the Franciscans would play a very important role in the creation of linguistic knowledge on Berber varieties. This history is rather well known. A few books were published in the first half of the twentieth century: the Gramática de la lengua rifeña, in 1905, by Pedro Hilarión Sarrionandia (1865-1913); the Diccionario español-rifeño, in 1944, by Esteban Ibáñez (1914-1998) (see also Ibáñez, 1949); the Diccionario español-senhayi (dialect bereber de Senhaya de Serair), in 1959, by Esteban Ibáñez; the Manual de conversación bereber rifeño, by the aforementioned Ángel Muñoz Bosque; and the Rudimentos de bereber rife$\tilde{n} o$, in 1944, by Ginés Peregrín Peregrín. Undoubtedly, these authors had a good command of the language. As an example, in Sarrionandia's obituary published in the journal El Siglo Futuro in 1913, the year of his death, a certain S.R.O. (J.R.O. in other versions of this obituary published in the Spanish press) wrote the following: "Proof of how perfectly Father Sarrionandia spoke the Riffian language may be seen in how on a particular occasion some natives wanted to take him with them, because they mistook him for a family member who had disappeared years before" (El Siglo Futuro, 18 August 1913, p. 2).

In the times of colonial rule, the teaching of Berber in the territory of the Spanish Protectorate took place mainly in military academies. The most important were the Academia de Arabe y Bereber de Tetuán founded in the Jbalan city in 1929, and the Academia de Arabe Vulgar de Melilla founded in the Riffian city in 1904, where a class in Chelja was established by royal decree in January 1914. In 1918, the teacher in Melilla was Cándido López Castillejos, and the future Riffian resistance leader Abdelkrim el-Khattabi worked there as a language assistant. Indeed, some Spanish officials studied with him, such as colonels Morales and Riquelme, chiefs of the Oficina de Asuntos Indigenas (Indigenous Affairs Office)

In 1920, Mariano Segarra, lieutenant in the Reserve Infantry, was appointed profesor auxiliar (teaching assistant) of the class in chelja at the academy in Melilla. In 1922, another class of Riffian was to be established. The location was the newly-founded Escuela General Técnica (Technical General School), where there were chairs of Muslim law, Chelja, and "vulgar and literal Arabic". In 1923, the appointed teaching assistant was Sidi Mohamed Ben Merini, and in 1931 Mohamed Mohatar Boaza held the same position in Melilla (Boletín oficial de la zona de protectorado español en Marruecos, 10 March 1931). In 1948 , in the late protectorate days, a chair of Berber language (cátedra de lengua bereber) was created in the Centro de Estudios Marroquies (Center for Moroccan Studies). The teacher was Ginés Peregrín Peregrín.

Along with the military academies, we have some other examples. In 1904, in Tangier, the Escuela Superior de Árabe, de Rifeño y de Estudios Orientales (High School of Arabic, Riffian and Oriental Studies) was established, where two yearly six-month courses took place. Among the taught subjects, we find Moroccan Arabic, classical Arabic, Chelja, History and Islamic institutions... It was part of the Instituto Español de Marruecos
(Spanish Institute of Morocco), and it was located in the Casa Braunschwig, an old commercial house. In July 1905, the Instituto Español de Marruecos offered a curso gratuito de lengua xelja (free Chelja language course), to be held in the Sindicato Español (Spanish Trade union) in Tangier (El África Española, 15 July 1905).

In the meantime, the teaching of Berber in peninsular Spain was extremely uncommon. Pascual Meneu (18571934), a Hebrew and Arabic professor, stands as a rare example. He held a chair of the Berber language from 1911 to 1912 at the University of Salamanca, and he also planned to publish a Berber dictionary with words he had compiled in the south of Morocco. As the press of the time stated, Meneu "proposed that these materials should be used for the publication of a grammar book for the Berber language in general and another one specifically for Riffian" (El Adelanto, 01 June 1911 and 27 September 1911). In Madrid, a so-called Centro de instrucción comercial (Center for Commercial Instruction) ${ }^{6}$ advertised in the press for a teacher who could give classes of "Arabic language (Riffian dialect)": “(...) applications are accepted for the competitive selection to fill the vacant posts for teachers of the following classes: Higher arithmetic ... French language, Arabic (Riffian dialect)..." (El País, 25 August 1912). Another academy offered lessons of "Arabic and Chelja" by a professor called A. Benguigui in Martínez Campos street in the city of Melilla (El Telegrama del Rif, 1 September 1915). The professor was the Jewish-Moroccan Abraham Benguigui. In 1916, he was teaching chelja at the Polytechnic School of Melilla ( $E l$ Telegrama del Rif, 4 March 1916). He was also working as an interpreter in the Policía Indígena (Indigenous Police Force), and he obtained a "diploma de chelja" in the year 1922 (El Telegrama del Rif, 30 March 1922)

In the years of the Spanish Protectorate (19121956), we can see that a complex relationship existed between the recognition and learning of Berber varieties, interpretation and translation, and colonial power dynamics. We know of some interpreters of Berber varieties. In the early years, many local Riffian interpreters worked for the Spaniards. This was the case in 1922 of a local interpreter referred to as Ami-Adrian, identified as a "Riffian interpreter", probably referring to the variety that he mastered. In that same year, the navy created the post of Arab interpreter (Royal Order Day 23), which was filled by Abderrajaman Ben Mohamed, a sergeant from the Fuerzas regulares indigenas numero $3^{7}$ from Ceuta, who was said to "possess vulgar Arabic and Riffian dialect" (Diario oficial del ministerio de marina, 2 June 1922). Among the Spanish interpreters, we find the aforementioned Cándido López Castillejos, Abdelkrim el-Khattabi himself, Fernando Martínez de Escalera, Cristóbal Benítez, Manuel Martínez Martín, and Ginés Peregrín Peregrín. Peregrín is a very interesting figure. He was an interpreter in the cuerpo de interpretación de Árabe y Bereber ${ }^{8}$ and a teacher at the Centro de Estudios Marroquíes (Center for Moroccan Studies) in Tetouan, and he wrote a book called Rudimentos de bereber rifeño, published in 1944. 
Among the Spaniards who learnt any Berber varieties in those days, we also find a very interesting group, the so-called "renegades". A press article published in 1909 describes fourteen Spaniards who were with the Rogui of Zeluan: "(...) their dress is identical to that of the cabilenos; they speak 'Chelja' (Riffian dialect) perfectly, and all their European customs disappear so that they adopt only the Moorish ones" (El Imparcial, 17 August 1909). In 1929 , the linguistic practices of these renegades are characterised in the following way:

Capaz has been (...) with the cabilas in the interior, and on many occasions his eye has been sharp enough to grab a typical Riffian by the ponytail who, despite their purest "Chelja", turns out to be a native of Mataró or Chiclana. It should not be forgotten that, although in Morocco our state is rolling out a civilising and protective mission, the Spanish citizen is not like the British citizen, who is able to remain impermeable to the medium; the Spaniard - and this is perhaps one of their best qualities - knows how to adapt to the medium, and any Andalusian citizen with fifteen or twenty years of Africa behind them becomes more Mohammedan than Mohammed (Ahora, 11 January 1934).

\section{THE (POST)COLONIAL ARCHIVE: UNTRIBING MOROCCO?}

What do I mean exactly by a "(post)colonial archive"? In the last few years, the calls for a "postcolonial archive" have grown louder, but with limited exceptions, this "postcolonial archive" has been constructed as largely metaphorical. Indeed, the "(post)colonial archive" is a project that takes knowledge-making into account, and intends to generate intellectual resources which are meaningful. For it not to be the "direct descendant of the colonial archive" it requires "a different set of research tactics and interpretive strategies" (Lal, 2015, p. 35). To a great extent, digitisation has paved the way for the decentralisation and socialisation of knowledge. Textual and visual materials become accessible to wider and spatially disperse audiences through online platforms. In the case of Berber varieties, this is having a notorious impact, because colonial discourses are far from being deeply discussed and are instead amplified. The use of the aforementioned maps by the local populations helps reaffirm colonial perceptions of cultural/linguistic diversity and ethnic identity. As Lotfi Sayahi (2015, p. 62) has recently put it: "Spain's policies were severely conditioned by a hyper-awareness of the existing ethno-religious divisions". Digitisation could have opened up a path for the critical examination of the colonial archive, but instead, with some frequency, it has helped reaffirm colonial discourses. At any rate, it is very interesting to see how the contents of the colonial archive are used, appropriated, repurposed and challenged by new audiences. In this sense, the (post)colonial archive might afford all of us a reimagining of northern Morocco, particularly of Berberophony in the Rif.

A clear example of the (post)colonial archive and identity would be what has been called the "untribing" of the (post)colonial archive. In the course of the 19th and $20^{\text {th }}$ centuries, a very clearly European and North American notion of "tribe" was imported into Morocco. Thus, many of our present-day discourses on Morocco deal with "tribes" and "confederacies", somehow obscuring present-day administrative organisation and reforms, as well as new local socio-political articulations. In a sense, many of the textual and visual materials produced in the 19 th and 20th centuries are trapped in broad-stroke timeless tribal/confederal or ethnic categories that efface or erase the existence of other earlier or co-existent forms of identification. Maps (like those I have mentioned before) are commonly taken to be true reflections of the status quo, but there is an urgent need to rethink their production, their reproduction and their diffusion. If we take into account what I have previously explained about linguistic diversity in northern Morocco and Spanish colonial discourses and actions on Berber and Berberophony, we can see to what extent the aforementioned maps only provide us with a still image of both linguistic and socio-political diversity. As I have stated before, the Beni Zeroual provide a quite interesting case example of the different French and Spanish understandings of local forms of socio-political organisation. The debate over its nature as a political entity concerns the Spanish and the French in the years of the occupation of Morocco, particularly in the last years of the Rif War (1921-27). The Spanish defended that it was a confederacy, while the French stated that it was a tribe. For the French, the Beni Zeroual were a tribe with five fractions: Ouled Kacem, Beni Brahim, Beni Melloul, Beni Bou Bane, and Beni $\mathrm{M}^{\prime} \mathrm{ka}$. In order to better determine the nature of the political organisation of the Beni Zeroual, the French military official Degendre had an interview with its leaders Sharifian leaders and caidal authorities - in 1926. The idea that Beni Zeroual was a confederacy rather than a tribe is maintained over time in Spanish accounts on the Rif War. Indeed, in 1940 the Spanish authorities published a document entitled Confederación de Beni Zerual. But in spite of the debate, the Beni Zeroual also appeared referred to as a tribe (tribu, cábila/kábila) in some Spanish texts, and as a confederacy (confédération) in some French texts. Indeed, the debate is linked to the possession of the land. What the French and the Spanish discuss is their right to colonise the territory of the tribe/ confederacy. At one point in the war, the Spanish would occupy two-thirds of its territory, but finally France would keep the entire territory as a part of its protectorate over Morocco. As it refers to linguistic identity, Beni Zeroual was thought to be a Berber confederacy whose members had lost their former Berberophony when they had been Arabised. In the case of the two other territorial groups addressed as confederaciones in the Spanish Protectorate, the French authorities or colonial writers never cast any doubt on their nature: Ghomara and Senhaja de Sraïr were also identified as confederacies by the French. In these cases, the present Berberophony was a proof of their socio-political identity. Language was taken as a sine qua non, in a rather circular reasoning on the nature 
of alliances and the linguistic identity of tribes. The two maps mentioned in this article, representing Ghomara and Senhaja de Sraïr, are fairly popular when it comes to representing the linguistic diversity in northern Morocco. Father Esteban Ibáñez's map is better known than the Mapa Sociológico, but both digitised items have been repeatedly reproduced locally, particularly since the 2000 s. Both maps, as I stressed before, put into circulation very determinate ideas of linguistic diversity in northern Morocco. The main idea that they convey is that three different varieties of Berber do exist, something which is nowadays contested through linguistic research. Thus, the postcolonial impact of digitised colonial records should not be dismissed. This article aimed at reflecting on the Spanish colonial recognition of linguistic diversity within the territory under its rule in the times of the Spanish and French Protectorates in Morocco (1912-1956). As I have shown, Spain did not promote research on Berber varieties, but its colonial action created long-lasting perceptions of linguistic and socio-political boundaries, which are reaffirmed in present-day local and extra-local contexts through the reproduction of digitised items kept in colonial archives.

\section{ACKNOWLEDGEMENTS}

This research was carried out within the framework of the $\mathrm{R}+\mathrm{D}$ Project "African Memories: Reconstructing Spanish Colonial Practices and Their Imprint in Morocco and Equatorial Guinea. Towards a Hispano-African Cultural Heritage" directed by Yolanda Aixelà-Cabré. Institución Milà i Fontanals of research in Humanities. Consejo Superior de Investigaciones Científicas (HAR2015-63626-P) (2016-2018). The English of the article has been revised by Tom Hardy

\section{ARCHIVES CONSULTED}

Biblioteca Nacional de España (BNE)

- Biblioteca Digital Hispánica (BDH)

- Hemeroteca Digital

Biblioteca Virtual de Prensa Histórica

Biblioteca Virtual del Ministerio de Defensa

Institut Cartogràphic i Geològic de Catalunya (ICGC)

\section{NOTES}

1 The exact date is unknown. See: http://bibliotecavirtualdefensa es/BVMDefensa/i18n/consulta/registro.cmd?id=7694 [accessed 26 February 2020]

2 "News on the language spoken in the Rif, aboriginal language in the whole of North Africa". It can be found, republished, in the Revista de geografia colonial y mercantil (1910).

3 "Teaching of the Berber language in Spain". This journal does not include page numbers.

4 Vocabulary of certain words in the Riffian dialect, which is derived from Arabic and in very small part from Spanish.

5 "phrases and adverbs".

6 Commercial education center.

7 Regular indigenous forces number 3 .

8 Arab and Berber interpretation unit.

\section{REFERENCES}

Ahora, 11 January 1934. http://hemerotecadigital.bne.es/issue.vm?id $=0029996196 \&$ search $=\&$ lang=es [accessed 26/February $/ 2020]$

Aixelà-Cabré, Yolanda (2017) "Exploring Euro-African pasts through an analysis of Spanish colonial practices in Africa (Morocco and Spanish Guinea)". Canadian Journal of African Studies/Revue canadienne des études africaines, 51 (1), pp. 2342. DOI: $10.1080 / 00083968.2016 .1276848$

Barclay, F., ed., (2013) France's Colonial Legacies. Memory, Identity and Narrative.Cardiff: University of Wales Press.

Berque, Jacques (1954) "Qu'est-ce q'une « tribu » nord-africaine?" In: L'eventail de l'histoire vivante: Hommage à Lucien Fèbvre. Paris: Armand Colin, pp. 261-271.

Boletín oficial de la zona de protectorado español en Marruecos, 10 March 1931. https://prensahistorica.mcu.es/es/publicaciones/ numeros por mes.do?idPublicacion $=1000483 \&$ anyo $=1931$ [accessed 26/February/2020]

Burke, Edmund (2007) "The Creation of the Moroccan Colonial Archive, 1880-1930". History and Anthropology, 18 (1), pp. 1-9. DOI: 10.1080/02757200600976127

Codera, Francisco (1899) "Enseñanza del Árabe vulgar”. Revista contemporánea, Año XXV, Tomo CXIV, vol. 1, 15 April 1899, pp. 36-43.

Comaroff, J. and J. (1992) Ethnography and the Historical Imagination. Boulder, Colorado: Westview Press.

Combs-Schilling, M. Elaine (1985) "Family and friend in a Moroccan boom town: The segmentary debate reconsidered". American Ethnologist, 12 (4), pp. 659-675. DOI: 10.1525/ae.1985.12.4.02a00040

Coon, Carleton (1931) Tribes of the Rif. Cambridge MA: Peabody Museum of Harvard University.

Diario oficial del ministerio de marina, 2 June 1922. http://bibliotecavirtualdefensa.es/BVMDefensa/i18n/catalogo imagenes/ grupo.cmd?path=115906 [accessed 26/February/2020]

Eickelman, Dale F. (1976) Moroccan Islam. Tradition and Society in a Pilgrimage Center. Austin: Texas University Press.

El Adelanto, 01 June 1911. https://prensahistorica.mcu.es/es/publicaciones/numeros_por_mes.do?idPublicacion=17420\&an yo $=1911$ [accessed $26 /$ Fe $\bar{b}$ ruary/2020]

El Adelanto, 27 September 1911. https://prensahistorica.mcu.es/es/ publicaciones/numeros por mes.do?idPublicacion=17420\&an yo $=1911$ [accessed 26/February/2020]

El África Española, 15 July 1905. https://prensahistorica.mcu.es/es/ publicaciones/numeros por mes.do?idPublicacion $=1002089 \&$ anyo $=1905$ [accessed 26/February/2020]

El Hannouche, Jamal (2008) Ghomara Berber. A brief grammatical survey. Leiden University, MA Thesis.

El Imparcial, "Los renegados", 17 August 1909. http://hemerotecadigital.bne.es/issue.vm? $\mathrm{id}=0000255251 \&$ search $=\&$ lang=es [accessed 26/February/2020]

El País, 25 August 1912. http://hemerotecadigital.bne.es/issue.vm?id $=0002425438 \&$ search $=\&$ lang $=$ en $[$ accessed $26 /$ February $/ 2020]$

El Siglo Futuro, 18 August 1913. http://hemerotecadigital.bne.es/issue.vm?id=0000314809\&search=\&lang=es [accessed 26/February/2020]

El Telegrama del Rif, 1 September 1915. https://prensahistorica. mcu.es/es/publicaciones/listar numeros.do?busq anyo $=1915 \&$ busq idPublicacion $=1000682 \&$ busq dia $=\&$ busq mes $=9$ \&posicion $=$ [accessed 26/February/2020]

El Telegrama del Rif, 4 March 1916. https://prensahistorica.mcu.es/ es/publicaciones/listar_numeros.do?busq_anyo=1915\&busq idPublicacion $=100068 \overline{2} \&$ busq dia $=\&$ busq $\operatorname{mes}=3 \&$ posicion $=$ [accessed 26/February/2020]

El Telegrama del Rif, 30 March 1922. https://prensahistorica.mcu. es/es/publicaciones/listar numeros.do?busq idPublicacion $=1000682 \&$ busq anyo $=19 \overline{2} 2 \&$ submit $=$ Buscar + en + todo $+e 1+$ añ o\&busq dia $=\&$ busq mes $=3 \&$ posicion $=26$ [accessed $26 /$ Febru$\operatorname{ary} / 2020]$

Geertz, Clifford, Geertz, Hildred and Rosen, Lawrence (1979) Meaning and Order in Moroccan Society: Three Essays in Cultural Analysis. New York: Cambridge University Press. 
Gellner, Ernest (1969) Saints of the Atlas. London: Weidenfeld and Nicolson.

González Vázquez, Araceli (2018) “Ghomara and Senhaja de Sraïr: Berbers at the Margins of History, or Berbers at the Margins of the Berbers? Colonial and Post-Colonial Discourse and Micropolitics". In: Aixelà Cabré, Y. (ed.) In the Footsteps of Spanish Colonialism in Morocco and Equatorial Guinea. Zurich: Lit Verlag, pp. 129-155 (Africanische Studien, 59).

Hamilton, C. and N. Liebhammer., eds. (2016) Tribing and untribing the Archive. Pietermaritzburg: University of Kwazulu-Natal Press.

Hart, David M. (1966) "Berber tribal alliance networks in pre-colonial North Africa: the Algerian saff, the Moroccan liff and the chessboard model of Robert Montagne". The Journal of North African Studies, 1, 2, pp. 192-205.

Hart, David M. (1970a) "Clan, lineage, local community and the feud in a Riffian tribe (AithWaryaghar, Morocco)". Peoples and cultures of the Middle East, 2, pp. 3-75.

Hart, David M. (1970b) "Conflicting models of a berber tribal structure in the Moroccan Rif: the segmentary and alliance system of the Aith Waryaghar". Revue des mondes musulmans et de la Méditerranée, 7 (1), pp. 93-99. DOI: 10.3406/remmm. 1970.1060

Hart, David M. (1984) "Segmentary systems and the role of 'five fifths' in tribal Morocco". In: Ahmed, A. S. and Hart, D. M. (eds.) Islam in Tribal Societies: From the Atlas to the Indus. London: Routledge, pp. 66-105.

Hart, David M. (1989) Rejoinder to Henry Munson, Jr., "On the Irrelevance of the Segmentary Lineage Model in the Moroccan Rif'. American Anthropologist, 91 (3), pp. 765-769.

Hart, David M. (1993) "Faulty models of North African and Middle Eastern tribal structures". Revue des mondes musulmans et de la Méditerranée, 68 (1), pp. 225-238. DOI: 10.3406/remmm.1993.2569

Hart, David M. (1996) "Segmentary models in Morocco". Journal of the Royal Anthropological Institute, 2 (4), pp. 721-723.

Ibáñez, Esteban (1944) Diccionario español-rifeño. Madrid: Imprenta de la viuda de E. Maestre.

Ibáñez, Esteban (1949) Diccionario rifeño-español (etimológico). Madrid: Instituto de Estudios Africanos.

Ibáñez, Esteban (1959) Diccionario español-senhayi (Dialecto bereber de Senhaya de Serair). Madrid: Instituto de Estudios Africanos.

Kraus, William (1998) Contestable identities: tribal structures in the Moroccan High Atlas. Journal of the Royal Anthropological Institute, 4 (1), pp. 1-22. DOI: 10.2307/3034425

Lafkioui, Mena (2007) Atlas linguistique des variétés berbères du Rif. Köln, Köppe.

Lal, Priya (2015) African Socialism in Postcolonial Tanzania. Between the village and the world. New York: Cambridge University Press.

Lobera, Cándido (1926) "La política bereber del Protectorado". África, Revista de Tropas Coloniales, 18 (Junio), p. 126.

Lobera, Cándido (1927) "El interventor y la función interventora de las kabilas". Revista África, enero, p. 1.

Montagne, Robert (1931) La vie politique et sociale des Berbères. Paris: Éditions du Comité de l'Afrique Française.

Mourigh, Khaled (2016) A Grammar of Ghomara Berber NorthWest Morocco). Köln: Köppe.
Munson, Henry (1981) "The mountain people of northwestern Morocco: tribesmen or peasants?" Middle Eastern Studies, 17 (2), pp. $249-255$.

Munson, Henry (1989) "On the irrelevance of the segmentary lineage model in the Moroccan Rif'. American Anthropologist, 91 (2), pp. 386-400.

Munson, Henry (1991) "The Segmentary Lineage Model in the Jebalan Highlands of Morocco". In: Joffé, E.H.G. and Pennell, C.R. (eds.) Tribe and State: Essays in Honour of David Montgomery Hart. Wisbech: Menas Press, pp. 48-68.

Munson, Henry (1993) "Rethinking Gellner's Segmentary Analysis of Morocco's Ait 'Atta”. Man, 28 (2), pp. 267-280.

Munson, Henry (1996) "Rethinking Gellner's Segmentary Analysis of Morocco's Ait 'Atta". Poznan Studies in the Philosophy of the Sciences and the Humanities, 48, pp. 291-308.

Muñoz Bosque, Ángel (1919) "La enseñanza del idioma bereber en España”. Nuevo Mundo, 24 October 1919.

Muñoz Bosque, Ángel (1919) Manual de conversación bereber rifeña. Madrid: Editorial Isaac Martínez.

Pascon, Paul (1971) "La formation de la société marocaine". Bulletin Economique et Sociale du Maroc XXXIII, pp. 1-27.

Peregrín Peregrín, Ginés (1944) Rudimentos de bereber rifeño. Tetouan: Imprenta El Mahdía.

Renisio, Amédée (1932) Étude sur les dialectes berbères des Beni Iznassen, du Rif, et des Senhaja de Sraïr: grammaire, textes et lexique. Paris: Ernest Leroux.

Reparaz, Gonzalo de (1927) "El fantasma africano". El Sol, 13 January 1927, p. 8.

Sarrionandia, Pedro Hilarión (1905) Gramática de la lengua rifeña. Tánger: Imprenta Hispano-arábiga de la Misión Católica.

Sarrionandia, Pedro Hilarión (1909) Noticia sobre la lengua que se habla en el Rif, lengua aborigen de todo el norte de Africa. Tánger: Imprenta de la Misión Católica.

Sarrionandia, Pedro Hilarión (1910) "Noticia sobre la lengua que se habla en el Rif, lengua aborigen de todo el norte de África". Revista de geografía colonial y mercantil, 7, 8, pp. 9-38.

Sayahi, Lotfi (2015) "España ante el mundo: Spain's colonial language policies in North Africa". Transmodernity: Journal of Peripheral Cultural Production of the Luso-Hispanic World, 5 (3), pp. 62-75.

Spivak, Gayatri Chakravorty (1985) "Can the subaltern speak? Speculations on widow-sacrifice", Wedge 7/8, pp. 120-130.

Spivak, Gayatri Chakravorty (1988) "Can the subaltern speak?". In: Nelson, C. and Grossberg, L. (eds.) Marxism and the Interpretation of Culture. Urbana: University of Illinois, 271-313.

S.R.O. (1913) El Rvdo. P. Pedro H. Sarrionandia. El Siglo Futuro, 18 August 1913, p. 2.

Stoler, Ann Laura (2002) "Colonial archives and the arts of governance”. Archival Science, 2 (1-2), pp. 87-109. DOI: 10.1007/ BF02435632

Stoler, Ann Laura (2008) "Imperial debris: Reflections on Ruins and Ruination". Cultural Anthropology, 23 (2), pp. 191-219. DOI: $10.1111 / \mathrm{j} .1548-1360.2008 .00007 . x$

Tilmatine, Mohand (2011) "La política cultural durante el protectorado español en Marruecos: el caso del bereber". Signos Lingüísticos, 5 (9), pp. 9-36.

Vial de Morla (pseudonym of Tomás García Figueras) (1944) “Estudios bereberes en España". La Vanguardia, 19 September 1944 , p. 1. 